\title{
Reducing iron deficiency anaemia due to heary menstrual blood loss in Nigerian rural adolescents
}

\author{
Fiona Barr ${ }^{1}$, Loretta Brabin ${ }^{1}{ }^{*}$, Shola Agbaje ${ }^{1}$, Fiekumo Buseri ${ }^{2}$, John Ikimalo $^{2}$ and \\ Nimi Briggs 2 \\ 'Liverpool School of Tropical Medicine, Pembroke Place, Liverpool L3 5QA, UK: ${ }^{2}$ University of Port \\ Harcourt, East-West Road, Choba, Port Harcourt, Nigeria
}

Submitted 20 Moy 1998: Accepted 31 July 1998

\begin{abstract}
Objective: Menstrual disorders are common in young women, and heavy menstrual blood losses (MBL) are an important cause of anaemia. Menstrual morbidity normally goes untreated in developing countries where cultural barriers also serve to mask the problems. We investigated the prevalence of menstrual morbidity, and measured MBL and its relationship to iron deficiency in a rural adolescent population. The rationale was to assess whether or not reducing heavy MBL could be part of a strategy to reduce iron deficiency anaemia.

Setting: Rural village in south-east Nigeria.

Design: Cross-sectional survey.

Subjects: The study included all non-pregnant, unmarried nulliparous girls $(<20$ years) who had menstruated, and who lived in K'Dere village.

Metbods: A field worker allocated to each girl completed a questionnaire, and supervised recovery and collection of soiled pads and ensured blood sampling. MBL was measured using the standard alkaline haematin method. Haemoglobin $(\mathrm{Hb})$, serum iron, transferrin saturation and protoporphyrin levels (ZPP) were also measured.

Results: 307 girls completed MBL measurements; $11.9 \%$ refused to participate. $12.1 \%$ had menorrhagia ( $>80 \mathrm{ml}$ ); median MBL was $33.1 \mathrm{ml}$. Menorrhagia was more frequent in girls who had menstruated for $>2$ years $(P=0.048)$, and had longer duration of menses $(P<0.001)$. Iron status as measured by haematocrit, serum iron, transferrin saturation and ZPP values was inversely related to MBL. Neither height nor body mass index for age was associated with current iron status.

Conclusions: The level of menorrhagia detected (12\%) may be an 'expected' level for a condition which often has no underlying pathology. Heavy MBL is one of the most important factors contributing to iron deficiency anaemia. Measures are needed to alleviate menstrual disorders, and improve iron status. Oral contraceptives can be part of a strategy to reduce anaemia, particularly for adolescents at high risk of unwanted pregnancies.
\end{abstract}

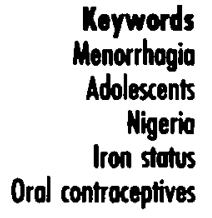

The most common symptomatic disorders of the menstrual cycle are the premenstrual syndrome, menorrhagia (excessive menstrual blood loss) and dysmenorrhoea (painful menstruation) ${ }^{1}$. Menorrhagia, which is defined as a measured blood loss in excess of $80 \mathrm{ml} \mathrm{cycle}^{-1}$, often has no pelvic or systemic cause and is usually referred to as dysfunctional uterine bleeding ${ }^{2}$. It is estimated to occur in $11-14 \%$ of women of reproductive age and when it occurs at menarche, may be associated with gynaecological abnormalities in later life ${ }^{3}$. Menstrual blood loss (MBL) can be objectively measured ${ }^{4,5}$, although in practice this is done only for research purposes and predominantly carried out in clinical settings. In developed countries assessment of blood haemoglobin or serum ferritin concentration is used as an aid to diagnosing menorrhagia since two-thirds of women with this condition suffer from iron deficiency anaemia ${ }^{6}$. Much is known about $\mathrm{MBL}$ as a result of a definitive Swedish study by Hallberg et $a l^{7}$, although that study included only 95 adolescent girls. Studies have not previously been conducted amongst African adolescents, and in fact, adolescents are usually excluded from MBL studies because of their irregular menstrual cycles ${ }^{8}$.

Menstrual disorders excite little attention amongst clinicians?. In Western countries, girls are routinely managed by primary care physicians on the basis of their symptoms, using drug regimes which are regarded as relatively effective in relieving symptoms ${ }^{10-14}$. Heavy MBL is an important indicator for 
prescribing the oral contraceptive pill as anovulatory drugs reduce MBL by $50 \%{ }^{15}$. The situation is very different in developing countries where girls are more likely to be anaemic due to poor diet and infections, and because they are rarely assessed for menstrual problems. Menses is a very private matter and girls/ women are often reluctant to talk about this subject. Nonetheless, Nigerian girls, when questioned as part of a study of reproductive tract infections, complained more about menstrual symptoms than other reproductive morbidity ${ }^{16}$. There is limited data from Nigeria on menstruation $^{17,18}$ so, as part of a programme to improve adolescent reproductive health, it was decided to investigate the relationship between MBL and anaemia. The main objective of this study was to measure the frequency of menorrhagia and iron deficiency in girls $<20$ years old.

\section{Subjects and methods}

\section{Study population}

The study was undertaken between January 1995 and May 1997 in K'Dere, an Ogoni farming/fishing village in Gokana District, $60 \mathrm{~km}$ from Port Harcourt, in the Niger Delta. The village is under-resourced, with no running water or electricity. There is one health centre which was underutilized because drugs and equipment were frequently lacking. The village has access to one secondary and four primary schools. Roads are reasonable and many people travel to Port Harcourt to work. Out-migration to Cameroun for extended fishing trips is also common among the Ogoni. The field officer (Barr) lived in the village for much of the study period. Her first 3 months were spent in sensitizing the community and establishing a framework for discussion of menstruation - a subject that is not openly discussed. During this period group discussions were held with a wide range of community members of both sexes, and the field officer became acquainted with local terminologies and beliefs. During this time a decision was made to use a standardized commercial brand of sanitary pads (supplied by Femina Hygenical Products Ltd, Port Harcourt, Rivers State, Nigeria) for the MBL study as these were preferred by adolescents to menstrual cloths, which had been considered as an alternative. Adolescents in this area do not use tampons. These early discussions also provided an opportunity to inform older women and to ask them to encourage eligible daughters to attend. All nonpregnant nulliparous girls $(<20$ years) who had begun to menstruate were eligible. Excluded were married adolescents who were judged likely to become pregnant, girls who became pregnant or had recently delivered, were chronically ill or not permanent village residents.

To identify eligible girls, visits were first made to local schools in March 1995 to compile class registers of girls. Girls were seen in class groups and asked to fill in a simple knowledge questionnaire on menstruation and related physiology, and a screening form in which girls indicated whether they had begun to menstruate and were willing to participate in the study. Then the field team began to visit and map every compound in the village by zone to identify other eligible girls who did not attend school, as well as school absentees. The register of girls was continuously updated to include girls who had just started to menstruate or had previously been absent from K'Dere. Two follow-up surveys were conducted to ensure all eligible girls were located. At this stage it was decided that, for all girls, distribution and collection of menstrual pads would be home-based since there was insufficient privacy in the schools. Moreover, girls normally left school to go home or into the bush to change sanitary wear. They preferred to deposit soiled pads at home.

\section{Study procedures}

Study girls were allocated by zone to one of three field workers who visited them in their compounds to take height and weight measurements and to explain study procedures. The final list of eligible girls was defined at this point. Heights and weights were measured with minimal clothing and no shoes, using a minimetre attached to a frame, and portable electronic (Seca) scales which were regularly calibrated. Since $10 \%$ of all screening forms had been repeated for quality control, and age reporting found to be variable, ages were reviewed using a calendar of local events and age of siblings to arrive at the most likely correct age.

During this period a field laboratory was established at the health centre and permanently staffed by a laboratory technologist specially trained in Liverpool. A regular water supply for the laboratory was obtained after sinking a bore-well. Procedures for collecting menstrual samples from girls and returning them to the laboratory were piloted with 32 girls. After this, enrolment for the MBL study began. A field worker made a first visit to the compound to deliver a set of 15 sanitary pads in a sealed plastic bag, together with two dark, pre-coded sealable bags for depositing used pads and a black heavy duty plastic bag for additional storage. Each girl was shown how to fill in a pictorial chart which recorded the number, the degree of staining of pads used and the extent of pain on each day. Girls were instructed carefully in the use of the pads and encouraged to try and collect all menstrual blood by changing frequently and mopping up spilt blood with a clean pad. They were advised to store pads only in the bags provided and to seal after use. Completing the chart was done over two consecutive menses although soiled pads were collected by the field worker only during the second menses. Girls were 
expected, and usually did, alert their field worker when the first menses commenced, allowing the field worker to check whether the chart was being completed properly. At the first visit a detailed questionnaire was also completed for each girl to establish the following: (a) basic sociodemographic information; (b) events surrounding first menses; (c) regularity of periods; (d) menstrual protection normally used; (e) menstrual morbidity; ( $f$ ) perception of blood loss; ( $g$ ) abortion; (h) contraceptive use; and (i) general health. After the first menses the field worker estimated when the second menses was due and issued a second set of pads. Return visits were made at least once, if not several times around that time to confirm start of menses. Girls were asked to go to the health centre to have a $5 \mathrm{ml}$ blood sample taken on the second or third day of bleeding. Those who did not attend were immediately followed up by the field worker. During and after menses the field worker collected pads and the pictorial chart, which were returned to the health centre.

\section{Laboratory procedures}

\section{Menstrual blood loss}

Measurement of MBL was by the alkaline haematin method established by Hallberg \& Nilsson ${ }^{4}$, modified by Newton et al. ${ }^{19}$ and Van Eijkeren et al. ${ }^{20}$, with some additional minor modifications. Briefly, all sanitary pads for each individual were stored in sealable bags in labelled buckets till the end of menses. All pads were then counted and transferred to a Cryovac plastic bag and blended, or pummelled with a known volume of $5 \% \mathrm{NaOH}$ for $15 \mathrm{~min}$, until completely homogenized, using a Stomacher Lab-Blender. An aliquot of homogenate was collected, filtered and incubated at room temperature for $10-15 \mathrm{~min}$. Simultaneously, $1 \mathrm{ml}$ venous blood from the same individual was diluted to $100 \mathrm{ml}$ with $5 \% \mathrm{NaOH}$ and incubated. Both the menstrual eluate filtrate and the diluted venous blood were mixed and the optical density (absorbency) determined with a spectrophotometer at $550 \mathrm{~nm}$ using $5 \% \mathrm{NaOH}$ as blank. Conversion to millilitres was done using the following equation:

$$
\operatorname{MBL}(\mathrm{ml})=\frac{\left(\mathrm{OD}^{550} \text { menstrual eluate }-\mathrm{OD}^{550} \text { blank pads }\right) \times V}{\left(\mathrm{OD}^{550} \text { venous blood }\right) \times 100}
$$

where $V=$ volume of $5 \% \mathrm{NaOH}$ used for the extraction and 100 is the dilution factor for the venous blood. Occasionally sample readings did not fall within the range of the spectrophotometer, so the menstrual eluate was further diluted, the samples re-read and the following equation used:

$\operatorname{MBL}(\mathrm{ml})=\frac{\left[\left(O D^{550} \text { menstrual eluate } \times \text { DF }\right)-O D^{550} \text { blank pads }\right] \times V}{\left(O D^{550} \text { venous blood }\right) \times 100}$ where DF equals the dilution factor of the menstrual eluate. It was noted that, when five unused sanitary napkins were mixed with $5 \% \mathrm{NaOH}$, they gave an absorbency reading of 0.003 . To offset this, a colour effect was calculated and abstracted from the total for each individual. To validate the extraction process, known volumes of venous blood were used to check the accuracy of the recovery procedures.

\section{Determination of iron status}

Following venepuncture, haemoglobin ( $\mathrm{Hb}$ ) was measured using a portable haemoglobinometer (HemoCue Ltd, UK). The haematocrit (HCT) was determined using heparinized blood in a micro-HCT centrifuge, and the mean cell $\mathrm{Hb}$ concentration (MCHC) calculated using the $\mathrm{HCT}$ and $\mathrm{Hb}$ values. Zinc protoporphyrin (ZPP) levels were measured using a dedicated haemofluorometer (Protofluor Z, Helena Laboratories, UK). Blood samples for the determination of serum iron were allowed to clot, and the sera immediately separated and frozen at $-20^{\circ} \mathrm{C}$ until they could be processed in batches. Serum total iron, unsaturated iron-binding capacity (UIBC), total ironbinding capacity (TIBC) and transferrin saturation (TS) were measured using a commercial kit (Sigma Diagnostics, UK). Values for $\mathrm{Hb}$ of $<12 \mathrm{~g} \mathrm{dl}^{-1}$, for

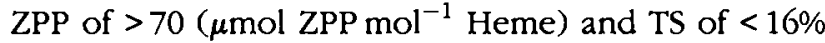
were classed as deficient ${ }^{21}$. British growth data were used for comparison with Nigerian data ${ }^{22,23}$

\section{Malaria blood slide}

A thick film was prepared using Giemsa stain. Slides were read by a trained microscopist and batches of slides were returned to Liverpool for cross-checking.

\section{Data analysis}

Data were entered in EpiInfo and FoxPro and analysed using SPSS for Windows Release 7 (1995) and Minitab for Windows Release 11.12 (1996). Descriptive statistics (means, medians, standard deviations and quartile deviations) were used for summarizing $\mathrm{MBL}$ in relation to other factors. Both parametric ( $t$-test, Pearson's correlation test, etc.) and non-parametric (Rank correlation test, Mann-Whitney rank sum test and chi-square test) approaches were used where appropriate, for comparison between and among groups.

\section{Permission and etbical clearance}

These were given by the Ethical Committee of the University of Port Harcourt Teaching Hospital. During the study, girls complaining of dysmenorrhoea were treated with paracetamol or indomethacin, and if necessary referred to the team's consultant gynaecologist (Ikimalo). Anaemia and other ailments were also treated. After the study when MBL results were known, menorrhagic girls were referred to the gynaecologist 
Table 1 Distribution of MBL in total population $(n=307)$

\begin{tabular}{lrc}
\hline Blood loss $(\mathrm{ml})$ & No. & $\%$ \\
\hline$\leq 20$ & 73 & 23.8 \\
$20.1-40.0$ & 115 & 37.5 \\
$40.1-60.0$ & 61 & 19.9 \\
$60.1-80.0$ & 21 & 6.8 \\
$>80$ & 37 & 12.1 \\
\hline
\end{tabular}

for pelvic examination and ultrasound scan (portable Siemen's Sonoline 1300 with a $3 \mathrm{MHz}$ linear probe).

\section{Results}

Of 385 girls considered eligible 19 immediately refused to participate (4.9\%). Over the 12 months it took to collect the MBL data, 19 more girls became ineligible because of pregnancy, sickness or migration. Ten girls with irregular periods, who entered the MBL study in the final months, did not menstruate for a second time, and 27 girls did not complete all procedures. Three girls whose pad collection was considered unreliable were omitted from the analysis. Of the total of 337 eligible girls who remained in the study, the refusal rate was $11.9 \%$ (46) girls. Data on iron status was available for 310 girls and MBL data for 307 . Of the girls 118 were $\leq 16$ years and 189 were $17-19$ years.

The distribution of MBL for this population of girls $(n=307)$ is shown in Table 1 . Median MBL was $33.1 \mathrm{ml}$ and $12.1 \%$ of girls had heavy blood loss $(>80 \mathrm{ml})$. Distribution of MBL was skewed with $4.0 \%$ of girls having an MBL in excess of $120 \mathrm{ml}$. Median MBL at the 90th percentile was $88.9 \mathrm{ml}$. No difference in MBL was observed in relation to age (Table 2). Sixty-five girls were unable to state their age of menarche. Four of $24(16.7 \%)$ girls who reported starting menarche early

Table 2 Distribution of MBL by age and year of menarche

\begin{tabular}{|c|c|c|c|c|}
\hline \multirow[b]{3}{*}{ Age/menarche } & \multicolumn{4}{|c|}{ MBL (ml) } \\
\hline & \multirow{2}{*}{\multicolumn{2}{|c|}{$\begin{array}{c}\text { Median } \\
\text { (quartile deviation) }\end{array}$}} & \multicolumn{2}{|c|}{$\geq 80 \mathrm{ml}$} \\
\hline & & & No. & $(\%)$ \\
\hline $\begin{array}{l}\text { Age (yeals) } \\
14-15 \\
16-17 \\
18-19\end{array}$ & $\begin{array}{l}32.5 \\
32.1 \\
34.5\end{array}$ & $\begin{array}{l}(15.4) \\
(14.2) \\
(21.1)\end{array}$ & $\begin{array}{c}4 / 44 \\
16 / 136 \\
17 / 127\end{array}$ & $\begin{array}{r}9.1 \\
11.8 \\
13.4\end{array}$ \\
\hline$P$ value & \multicolumn{2}{|c|}{$0.91 \dagger$} & \multicolumn{2}{|c|}{$0.75 \ddagger$} \\
\hline $\begin{array}{l}\text { Years since menarche } \\
0-2 \\
>2\end{array}$ & $\begin{array}{l}34.1 \\
29.7\end{array}$ & $\begin{array}{l}(13.2) \\
(18.2)\end{array}$ & $\begin{array}{r}9 / 124^{*} \\
18 / 118\end{array}$ & $\begin{array}{r}7.3 \\
15.3\end{array}$ \\
\hline$P$ value & \multicolumn{2}{|c|}{$0.84 \dagger$} & \multicolumn{2}{|c|}{$0.048 \ddagger$} \\
\hline
\end{tabular}

"65 girls were unable to state age of menarche. $t$ Difference in median values.

$¥$ Difference in proportions.
( $\leq 12$ years), compared to $11.0 \%(19 / 173)$ starting menarche at age 13-14 years and 8.9\% (4/45) of girls starting menarche late ( $\geq 15$ years), had an MBL $\geq 80 \mathrm{ml}$ but these differences were not significant. However, of girls who had attained menarche within the last 2 years, $7.3 \%$ had an $\mathrm{MBL}>80 \mathrm{ml}$ compared to $15.1 \%$ of girls who had been menstruating for at least 2 years $(P=0.048)$ (see Table 2). Most menses were of 4 days duration with a median blood loss of $33.4 \mathrm{ml}$ (Table 3). When menses lasted 6 or more days, median MBL was $68.7 \mathrm{ml}(P<0.001)$. Two girls with MBL $>80 \mathrm{ml}$ were a set of twins. Of girls with menorrhagia $4.8 \%$ also complained of severe dysmenorrhoea. The total proportion of girls suffering with either menorrhagia or moderate/severe menstrual pain was $31.0 \%$.

Table 4 shows that as MBL increased, iron deficiency, as measured by several indicators, also increased: HCT $(P=0.03)$, serum iron $(P=0.05)$, TS $(P=0.03)$ and ZPP $(P=0.006)$. Hb levels also decreased but not significantly $(P=0.06)$. Mean $\mathrm{Hb}$ was $12.0 \mathrm{~g} \mathrm{dl}^{-1}$ ( \pm 1.0 ). Of all girls $40.3 \%$ had $\mathrm{Hb}$ values below $12 \mathrm{~g} \mathrm{dl}^{-1}$ but moderate to severe anaemia $\left(<10 \mathrm{~g} \mathrm{dl}^{-1}\right)$ was uncommon. The effect of MBL on iron status is further demonstrated in Fig. 1 which shows the distribution of MBL for 103 girls with adequate iron status compared to 200 with deficiencies ( $\mathrm{Hb}<12 \mathrm{~g} \mathrm{dl}^{-1} ; \mathrm{ZPP}>70$; TS < 16\%). Girls with a positive malaria smear ( $3.5 \%$ of all girls) were excluded from both groups. In girls with evidence of iron deficiency or anaemia, median MBL was $36.4 \mathrm{ml}$ compared to $29.3 \mathrm{ml}$ in normal girls $(P=0.01)$. At MBL levels of $40.1 \mathrm{ml}$ and above, the proportion of girls with iron deficiency is higher than that of girls with normal values ( $44.5 \%$ compared to $28.2 \% ; P=0.006$ ). Table 5 examines the relationship between height and body mass index (BMI) for age, and iron status. This table uses the same groups as in Fig. 1. No significant differences in mean height or mean BMI were observed between iron deficient and iron sufficient girls of the same age. Although the correlation coefficient for height and age in iron deficient girls showed a positive association $(r=0.24 ; P=0.00)$ as did the mean BMI ( $r=0.22 ; \quad P=0.00)$, this should be interpreted cautiously since the confidence limits indicated no difference. The results suggest that there is little relationship between either height or BMI and current iron status, at least when mild iron deficiency is concerned. Twelve girls fell below the 2 nd centile height for age (British Reference Standards) and were considered stunted, of whom two had an $\mathrm{MBL}>80 \mathrm{ml}$. None of the girls was overweight, i.e. $>90$ th centile BMI for age.

Of girls $81.4 \%$ had regular menstrual cycles varying between 20 and 40 days in length, with a mean of 29 days $( \pm 4.0$ ). Their median MBL was $33.4 \mathrm{ml}$ (quartile deviation 16.9). For the remaining girls, with irregular 
Table 3 MBL distribution in relation to number of days menses

\begin{tabular}{lrccc}
\hline $\begin{array}{l}\text { Duration of } \\
\text { menses (days) }\end{array}$ & No. & Median MBL \pm quartile deviation (ml) & Lower quartile & Upper quartile \\
\hline 1 & 3 & $5.2 \pm 8.1$ & 4.4 & 20.6 \\
2 & 20 & $17.5 \pm 9.6$ & 9.7 & 28.8 \\
3 & 87 & $28.1 \pm 11.8$ & 20.1 & 43.7 \\
4 & 136 & $33.4 \pm 15.7$ & 20.4 & $5<0.001$ \\
5 & 49 & $46.4 \pm 26.1$ & 29.4 & 81.6 \\
6 or more & 11 & $68.7 \pm 56.2$ & 49.1 & 161.4 \\
\hline
\end{tabular}

cycles, median MBL was 29.6 (quartile deviation 17.1; $P=0.33$ ).

MBL was unlikely to have been affected by use of modern contraceptives since $53.3 \%$ were not sexually active. Of those who were, $16.1 \%$ had ever used the contraceptive pill or injectables, and none had been fitted with an intrauterine device. Girls' knowledge about effective pregnancy prevention was limited. Of all girls $30.0 \%$ had been pregnant at some time in the past but had not completed the pregnancy. There was no difference between the median MBL of girls with and without a history of abortion, nor in the proportion with menorrhagia. Most girls were also unable to specify when the 'safe period' occurred in the menstrual cycle: $60 \%$ said they had no idea.

Thirty girls who had completed MBL studies were randomly selected for a consistency study to see whether the magnitude of MBL was broadly the same over several cycles. Three girls dropped out after refusal during the first consistency cycle and 27 girls were followed successfully: five girls over three cycles and 22 over four cycles. MBL determinations for these girls are shown in Table 6 . Girls could not always be followed over consecutive months, and asterisks indicate months when girls did not participate. For some girls, fluctuations in MBL were observed which may have been real changes or errors of measurement. Occasional lower MBL totals were likely to reflect less care in girls' collection of pads and may account for the fluctuations observed for numbers 2, 10,16, 19 and 20 . The trend seen for numbers $6,7,9,15,22,24$ and 26 could similarly indicate changing commitment to the study, with more or less attention being given to pad collection over time. Two girls who would have been classed as menorrhagic on a single measurement in month 1 (numbers 13 and 14) consistently measured $>80 \mathrm{ml}$ blood loss in subsequent cycles.

Pelvic assessments were made of girls in whom menorrhagia had been detected during the study, to exclude some possible underlying causes. Physical examinations in all girls were normal. Ultrasound scan findings revealed two girls with subserous fibroids measuring 19 and $22 \mathrm{~mm}$ in diameter, respectively, which were not considered likely to have caused menorrhagia because of their position. One girl had a small $24 \mathrm{~mm}$ unilocular left ovarian cyst.

\section{Discussion}

The study confirmed a high prevalence of menstrual morbidity. Of these girls $12.1 \%$ suffered from menorrhagia, a figure in accordance with prevalences of 9$14 \%$ found amongst women aged 17-50 years in Western European populations ${ }^{7,24}$ but lower than the $20 \%$ found in China ${ }^{25}$. The accuracy of the results of this - or any other MBL study - cannot be definitively verified. While laboratory methods were standardized, there was no way of ensuring that all girls followed instructions or submitted their used pads. Verification is particularly difficult in a community-based study such as this, and was most obvious when girls were asked to continue the exercise over several months (see Table 6). However, any inaccuracy in MBL measurement will underestimate $\mathrm{MBL}$, and median values, as well as the prevalence of menorrhagia in this population, are most likely understated. This is particularly so because girls did not use tampons as well as pads, a fact which has been previously demonstrated to lead to underestimation of $\mathrm{MBL}^{7}$.

Since menorrhagia in adolescents generally has no

Table 4 Median values of various indicators of iron status in relation to levels of MBL

\begin{tabular}{lccccc}
\hline $\begin{array}{l}\text { MBL level } \\
(\mathrm{ml})\end{array}$ & $\begin{array}{c}\text { Haemoglobin } \\
\left(\mathrm{g} \mathrm{dl}^{-1}\right)\end{array}$ & $\begin{array}{c}\text { Haematocrit } \\
(\%)\end{array}$ & $\begin{array}{c}\text { Serum iron } \\
\left(\mu \mathrm{moll}^{-1}\right)\end{array}$ & $\begin{array}{c}\text { Transferrin saturation } \\
(\%)\end{array}$ & $\begin{array}{c}\text { Zinc protoporphyrin } \\
\left(\mu \mathrm{mol}_{\mathrm{ZPP}} \mathrm{mol} \mathrm{Heme}^{-1}\right)\end{array}$ \\
\hline$\leq 20$ & 12.1 & 36.0 & 11.0 & 21.9 & 24 \\
$20.1-40.0$ & 12.1 & 37.0 & 11.1 & 19.0 & 28 \\
$40.1-60.0$ & 12.1 & 36.0 & 9.7 & 17.8 & 22 \\
$60.1-80.0$ & 11.7 & 35.0 & 9.4 & 17.1 & 30 \\
$>80$ & 12.0 & 35.0 & 8.4 & 15.8 & 34 \\
$P$ value & 0.06 & 0.03 & 0.05 & 0.03 & 0.006 \\
\hline
\end{tabular}




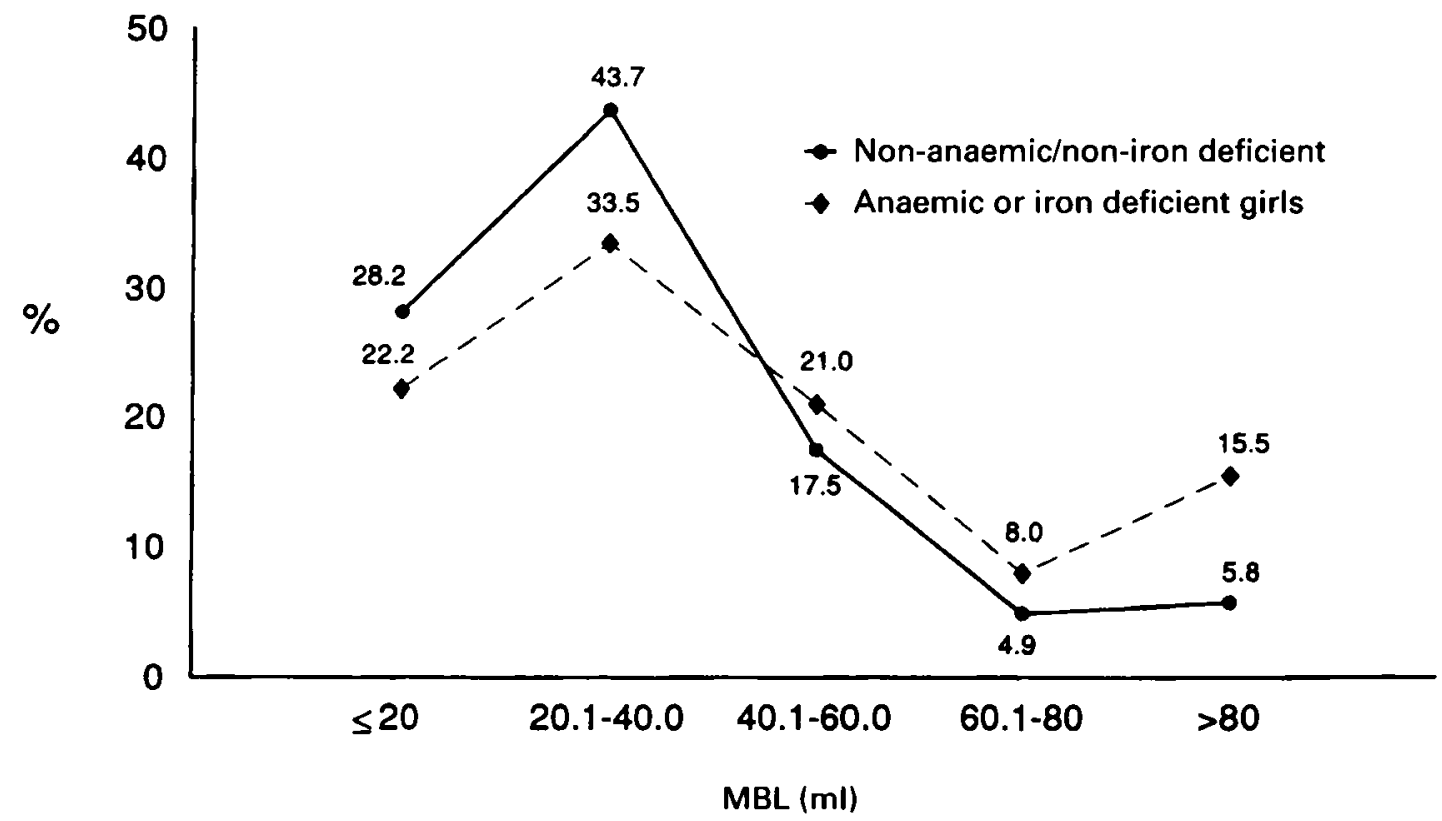

Fig. 1 Distribution of MBL in 103 girls with normal values for iron status compared to 200 with abnormal values

underlying pathology we suspect that a similar prevalence could be expected in any given adolescent population. Heavy blood loss may partly reflect genetic factors $^{26}$. Some authors regard menorrhagia as a selflimited condition on the basis of a study by Apter $e t$ al. $^{27}$ demonstrating that anovulatory cycles are common in the years following menarche. This has led to the presumption that unopposed oestrogen acting on the endometrium causes continual proliferation of the endometrium, which, when it does break down, causes a heavy menstrual loss. It has been suggested, therefore, that the pattern of menarche in the early years following menarche may be that of irregular, infrequent, extremely heavy periods with the passage of large $\operatorname{clots}^{28}$. This was not the pattern observed in this population study. In fact, the early cycles of girls

Table 5 Mean height and mean body mass index (BMI) for age in girls with adequate iron status compared to those with iron deficiency

\begin{tabular}{|c|c|c|c|c|}
\hline \multirow[b]{2}{*}{ Age (years) } & \multicolumn{2}{|c|}{ Mean height $(\mathrm{cm})$} & \multicolumn{2}{|c|}{ Mean BMI $\left(\mathrm{kg} \mathrm{m}^{-2}\right)$} \\
\hline & $\begin{array}{l}\text { Iron deficient } \\
\qquad(n=200)\end{array}$ & $\begin{array}{l}\text { Iron sufficient } \\
\quad(n=103)\end{array}$ & $\begin{array}{l}\text { Iron deficient } \\
(n=200)\end{array}$ & $\begin{array}{l}\text { Iron sufficient } \\
\quad(n=103)\end{array}$ \\
\hline 14 & $\begin{array}{c}153.2 \\
(150.6-155.9)^{*}\end{array}$ & $\begin{array}{c}153.6 \\
(143.8-163.3)\end{array}$ & $\begin{array}{c}18.7 \\
(17.5-19.8)\end{array}$ & $\begin{array}{c}19.0 \\
(17.1-20.9)\end{array}$ \\
\hline 15 & $\begin{array}{c}154.0 \\
(151.6-156.3)\end{array}$ & $\begin{array}{c}157.5 \\
(153.1-161.8)\end{array}$ & $\begin{array}{c}18.9 \\
(18.1-19.7)\end{array}$ & $\begin{array}{c}18.0 \\
(17.3-18.8)\end{array}$ \\
\hline 16 & $\begin{array}{c}157.4 \\
(156.1-158.6)\end{array}$ & $\begin{array}{c}154.5 \\
(152.1-156.8)\end{array}$ & $\begin{array}{c}19.0 \\
(18.5-19.5)\end{array}$ & $\begin{array}{c}19.8 \\
(19.0-20.5)\end{array}$ \\
\hline 17 & $\begin{array}{c}156.4 \\
(154.1-158.7)\end{array}$ & $\begin{array}{c}160.2 \\
(158.4-162.0)\end{array}$ & $\begin{array}{c}19.2 \\
(18.5-19.8)\end{array}$ & $\begin{array}{c}19.8 \\
(19.0-20.5)\end{array}$ \\
\hline 18 & $\begin{array}{c}158.8 \\
(156.9-160.6)\end{array}$ & $\begin{array}{c}156.7 \\
(153.7-159.4)\end{array}$ & $\begin{array}{c}19.4 \\
(19.0-19.9)\end{array}$ & $\begin{array}{c}19.8 \\
(19.1-20.6)\end{array}$ \\
\hline 19 & $\begin{array}{c}159.0 \\
(156.6-161.4)\end{array}$ & $\begin{array}{c}158.6 \\
(156.6-160.6)\end{array}$ & $\begin{array}{c}20.1 \\
(19.4-20.9)\end{array}$ & $\begin{array}{c}19.3 \\
(18.8-19.9)\end{array}$ \\
\hline $\begin{array}{l}\text { Correlation } \\
\text { coefficient }(r)\end{array}$ & $\begin{array}{c}0.24 \\
P=0.00 \\
(0.11-0.37)^{*}\end{array}$ & $\begin{array}{c}0.17 \\
P=0.09 \\
(-0.03-0.35)\end{array}$ & $\begin{array}{c}0.22 \\
P=0.00 \\
(0.08-0.35)\end{array}$ & $\begin{array}{c}0.10 \\
P=0.31 \\
(-0.10-0.29)\end{array}$ \\
\hline$r^{2}$ & $6 \%$ & $3 \%$ & $5 \%$ & $1 \%$ \\
\hline
\end{tabular}


Table 6 Consistency of MBL in individual girls over three or four menstrual cycles

\begin{tabular}{|c|c|c|c|c|c|c|c|}
\hline \multirow[b]{2}{*}{ Study no. } & \multicolumn{7}{|c|}{ Time period of consistency study } \\
\hline & Month 1 & Month 2 & Month 3 & Month 4 & Month 5 & Month 6 & Month 7 \\
\hline 1 & 37.92 & 23.50 & 39.55 & • & $\star$ & $\star$ & $\star$ \\
\hline 2 & 22.00 & 15.34 & 5.26 & 2.06 & $*$ & * & $*$ \\
\hline 3 & 43.72 & • & 50.22 & 46.07 & $*$ & 59.86 & $\star$ \\
\hline 4 & 35.77 & 21.47 & 34.53 & 24.63 & $\star$ & - & $\bullet$ \\
\hline 5 & 39.06 & 28.35 & $\star$ & + & 30.68 & 36.38 & $\star$ \\
\hline 6 & 23.72 & 20.25 & $\star$ & 14.55 & 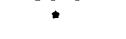 & 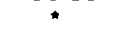 & $\star$ \\
\hline 7 & 25.91 & 21.57 & 22.08 & 16.63 & 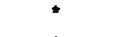 & $\star$ & $*$ \\
\hline 8 & 36.67 & 40.55 & 23.40 & 27.08 & • & 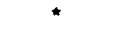 & * \\
\hline 9 & 29.71 & $\star$ & 31.23 & 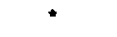 & * & 46.19 & $\star$ \\
\hline 10 & 27.73 & 40.67 & $\star$ & 23.27 & 15.04 & $\star$ & $\star$ \\
\hline 11 & 44.80 & 20.36 & 34.24 & 40.36 & • & $\star$ & $\star$ \\
\hline 12 & 30.15 & 64.89 & 102.57 & 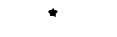 & $\bullet$ & 37.86 & $\star$ \\
\hline 13 & 98.70 & 84.59 & 90.56 & $\star$ & 80.16 & " & $*$ \\
\hline 14 & 176.22 & 121.35 & 186.20 & 131.08 & $\star$ & $*$ & • \\
\hline 15 & 52.30 & 37.04 & • & 23.02 & 15.68 & $\star$ & $\star$ \\
\hline 16 & 51.45 & 3.60 & 82.35 & • & • & * & 40.56 \\
\hline 17 & 13.89 & 10.17 & 34.15 & $\star$ & 18.84 & 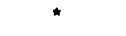 & $*$ \\
\hline 18 & 32.01 & 26.86 & 30.92 & * & 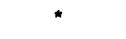 & 20.28 & • \\
\hline 19 & 39.02 & 62.39 & 46.72 & 54.88 & $*$ & $*$ & * \\
\hline 20 & 1.98 & 14.89 & $\star$ & 26.4 & * & 15.64 & * \\
\hline 21 & 25.52 & 22.73 & 20.25 & 25.29 & * & $*$ & * \\
\hline 22 & 22.94 & 17.33 & 16.51 & 11.52 & $\bullet$ & * & $\bullet$ \\
\hline 23 & 11.69 & 15.36 & 19.41 & * & * & 17.94 & $*$ \\
\hline 24 & 44.60 & 29.27 & 24.64 & $\star$ & 21.33 & $\star$ & * \\
\hline 25 & 59.24 & 51.08 & 68.81 & 57.57 & * & $\star$ & $\bullet$ \\
\hline 26 & 15.34 & 42.69 & 58.30 & 67.81 & * & $\star$ & • \\
\hline 27 & 19.59 & 33.38 & 18.95 & $•$ & * & * & • \\
\hline
\end{tabular}

"Girl not followed in this month.

who had only recently started to menstruate were less likely to be very heavy than those in girls with established cycles (see Table 2). The consistency data indicated that girls classified as menorrhagic, remained so over four or five cycles (see Table 6). Hallberg et al. $^{29}$ also consider that the pattern of blood loss is established and constant from menarche throughout life.

If the Swedish and Nigerian studies are indicative of the expected prevalence of menorrhagia, a minimum prevalence of $12 \%$ amongst adolescents is cause for concern. The definition of normality for MBL has been based on the effect of blood loss on iron balance ${ }^{7,30}$. The more marked the deficiency of iron and the longer its duration, the higher the probability that $\mathrm{Hb}$ concentration, TS, red cell protoporphyrin and red cell indices will be affected ${ }^{15}$. A total of $40 \%$ of girls in this population were anaemic $\left(<12 \mathrm{~g} \mathrm{dl}^{-1}\right)$ and it is likely that MBL was the most important factor contributing to anaemia. Only $3.5 \%$ of girls had malaria parasitaemias, and $S$. baematobium is not thought to be endemic in this area of Nigeria. Both this (see Table 5) and a previous anthropometric survey of girls in K'Dere, suggest a relatively well-nourished population $^{31}$. For $60 \%$ of these girls iron intake was sufficient to prevent anaemia, even though iron stores may have been reduced at a critical stage of reproductive life, i.e. in the years leading up to pregnancy. Elsewhere, in areas where iron intake is lower, many more girls would become anaemic at lower levels of $\mathrm{MBL}^{32}$. A recent study in Malawian girls for example, found a much higher proportion of moderately and severely anaemic girls, whose daily iron intake would be unlikely to offset even moderate menstrual losses ${ }^{33}$.

Responding to anaemia in non-pregnant adolescent girls must depend on the context in which that anaemia occurs and the level of dietary insufficiency. In this Nigerian population, diet was apparently reasonable but there were other factors to consider. Many girls had unwanted pregnancies and abortions and during the course of this study about $1 \%$ of eligible unmarried girls became pregnant and two deaths occurred as a result of induced abortion. Of all girls $30 \%$ had been pregnant previously, while an earlier study reported that girls gave histories of several abortions ${ }^{16}$. In an adolescent population where contraception is desired (and is culturally acceptable), the combined oral contraceptive pill would be the first choice for treating menorrhagia, although randomized control trials of the newer lower dose preparations are still needed ${ }^{34,35}$. They can be used by healthy, non-smoking girls without risk factors for cardiovascular disease ${ }^{36}$ although there may be some increased risk of breast cancer in girls using oral contraceptives. The Collaborative Group on Hormonal Factors in Breast Cancer ${ }^{37}$ concluded that there is an increased risk in the order of 0.5 excess cancers per 100,000 women for use at the age of 16-19 years. In Nigeria, this risk has to be set against the risk of 
complications of induced abortions, including long-term morbidity or death, for girls with no regular access to contraception. Combined oral contraceptives also help to reduce uterine cramps and make cycles more regular ${ }^{36}$.

Contraceptive use reduces iron losses and has a positive effect on iron balance, especially for those in the higher MBL range ${ }^{38}$. Hallberg \& Rossander-Hultén ${ }^{15}$ estimated that in a Swedish population using the pill, $\mathrm{MBL}$ was on average $35 \%$ lower, though there is a time factor involved, with iron balance improving by about $80 \mathrm{mg}$ iron year ${ }^{-1}$. The effect on iron balance in a less well-nourished population, however, would probably be more dramatic, provided that pills were taken regularly. Compliance with taking oral contraceptives can be problematic. However, one study in an inner city American family planning clinic has demonstrated that an important predictor of consistent oral contraceptive use among adolescents was their experience of alleviation of dysmenorrhoea during the first 3 months of contraceptive use $\mathrm{s}^{39}$. Where contraception is not required, as in the case of non-sexually active girls, prostaglandin synthesis inhibitors such as mefenamic acid will help to reduce and diminish MBL by $20-50 \%$ in those with unexplained menorrhagia with similar benefits on $\mathrm{Hb}$ status ${ }^{10}$. Adverse effects, largely of the gastrointestinal tract, are usually mild. Antifibrinolytics such as tranexamic acid have also been shown to reduce $\mathrm{MBL}$ by up to $54 \%^{12}$, but have had more reported side-effects such as nausea, diarrhoea and dizziness, with a few cases of intercranial arterial thrombosis, making widespread use more limited.

In conclusion, menstrual problems are of paramount importance to girls themselves - probably of more concern to them than anaemia. If girls know that health workers treat these problems, they are likely to report them. Encouraging girls to seek treatment for heavy MBL will help identify girls at increased risk of anaemia. Ideally girls presenting with menorrhagia should be screened for anaemia but if this is not feasible, prophylactic iron could be offered. Additionally, treating menstrual morbidity will, over a longer term, improve iron stores and improve the quality of life of girls with heavy periods. If treatment also involves use of oral contraceptives and delays pregnancy, the welldescribed competition for nutrients between a growing girl and her fetus will be offset till she is more mature with further nutritional benefit accruing ${ }^{40}$. Strategies to reduce anaemia which ignore menstrual complaints are likely to be less attractive to adolescents themselves, and will miss the opportunity to contribute more significantly to adolescent reproductive health.

\section{Acknowledgements}

The study was funded by the Department for International Development which takes no responsibility for any information provided or views expressed.

We thank the following: the community field workers: Mr T Gbarabe, Mr A Kinah, Ms S Naakuu; the K'Dere field support team: Ms S Kpegeloebel, Mr O Ogbuka, Ms H Bagbi, Ms N Tombari, Ms B Beaga and Mr T Naaben; the Port Harcourt support staff: Ms F Usim, Mr J Asolo, Mrs IS Alalibo; Mr G Harper for laboratory support in Liverpool; the late Ms $\mathrm{N}$ Dollimore for her contributions to the early development of the study; Femina Hygenical Products Itd, Port Harcourt for supplying sanitary products; Shell Petroleum Development Company (Nigeria), especially Dr OO Taiwo and the Medical Department for their continuing interest and support; the University of Port Harcourt Teaching Hospital, especially Dr OK Obunge, and Dr CT John for their cooperation and support; Rivers State Ministry of Women for facilitating administrative support to the study and the community of K'Dere, especially the girls who took part in the study, for their unwavering support and willing participation.

\section{References}

1 Rees MCP. Menstrual problems. In: McPherson A, ed. Women's Problems in General Practice. Oxford: Oxford University Press, third edition, 1993: 170-97.

2 Van Eijkeren MA, Christiaens GCML, Sixma JJ, Haspels AA Menorrhagia: a review. Obstet. Gymecol. Surv. 1989; 44: 421-9.

3 Southam AL. Dysfunctional uterine bleeding in adolescence. Clin. Obstet. Gynecol. 1960; 3: 241-51.

4 Hallberg L, Nilsson L. Determination of menstrual blood loss Scand. J. Clin. Lab. Invest. 1964; 16: 244-8.

5 Hurskainen R, Teperi J, Turpeinen Ul et al. Combined laboratory and diary method for objective assessment of menstrual blood loss. Acta Obstet. Gynecol. Scand. 1998; 77: 201-4.

6 Magos AI. Management of menorrhagia. Br. Med. J. 1990; 300: 1537-8.

7 Hallberg L, Höghdahl AM, Nilsson L, Rybo G. Menstrual blood loss - a population study. Acta Obstet. Gymecol. Scand. 1966: 45: 320-51

8 Rybo G. Menstrual blood loss in relation to parity and menstrual pattern. Acta Obstet. Gynecol. Scand. 1966; 45: 2545.

9 Kennedy S. Primary dysmenorrhoea. Lancet 1997; 349: 1116

10 Van Eijkeren MA, Christiaens GC, Geuze HJ, Haspels AA, Sixma JJ. Effects of mefenamic acid on menstrual hemostasis in essential menorrhagia. Am. J. Obstet. Gynecol. 1992; 166: 1419-28.

11 Preston JT, Cameron IT, Adams EJ, Smith SK. Comparative study of tranexamic acid and norethisterone in the treatment of ovulatory menorrhagia. Br.J. Obstet. Gymecol. 1995; 102: 401-6.

12 Bonnar J, Sheppard BL. Treatment of menorrhagia during menstruation: randomised control trial of ethamsylate, mefenamic acid and tranexamic acid. Br. Med. J. 1996; 313: 579-82.

13 Chuong CJ, Brenner PF. Management of abnormal uterine bleeding. Am. J. Obstet. Gynecol. 1996; 175: 787-92.

14 Barrington JW, Bowens-Simpson P. The levonogestrel intrauterine system in the management of menorrhagia. $\mathrm{Br} . J$. Obstet. Gynaecol. 1997; 104: 614-16. 
15 Hallberg L, Rossander-Hultén L. Iron requirements in menstruating women. Am. J. Clin. Nutr. 1991; 54: 1047-58.

16 Brabin L, Kemp J, Obunge OK, et al. Reproductive tract infections and abortion among adolescent girls in rural Nigeria. Lancet 1995; 345: 300-4.

17 Odujinrin OM, Ekunwe EO. Epidemiologic survey of menstrual pattems amongst adolescents in Nigeria. West Afr. J. Med. 1991; 10: 244-9.

18 Fakeye $O$, Adegoke A. The characteristics of the menstrual cycle in Nigerian schoolgirls and the implications for school health programmes. Afr. J. Med. Sci. 1994; 23: 13-17.

19 Newton J, Barnard G, Collins W. A rapid method for measuring menstrual blood loss using automatic extraction. Contraception 1977; 16: 269-82.

20 Van Eijkeren MA, Scholten PC, Christiaens GCML, Alsbach GPJ, Haspels AJ. The alkaline hematin method for measuring menstrual blood loss - a modification and its clinical use in menorrhagia. Eur. J.Obstet. Gynecol. Reprod. Biol. 1986; 22 : 345-51.

21 Gibson RS. Principles of Nutritional Assessment. New York: Oxford University Press, 1990.

22 Freeman JV, Cole TJ, Chinn S, Jones PRM, White EM, Preece MA. Cross-sectional stature and weight reference curves for the UK, 1990. Arch. Dis. Child. 1995; 73: 17-24.

23 Cole TJ, Freeman JV, Preece MA. Body mass index reference curves for the UK 1990. Arch. Dis. Child. 1995; 73: 25-9.

24 Cole SK, Billewicz WZ, Thomson AM. Sources of variation in menstrual blood loss. Br. J. Obstet. Gynaecol. 1971; 78: 9337.

25 Gao J, Zeng S, Sun B, Fan H, Han L. Menstrual blood loss and haematologic indices in healthy Chinese women. J. Reprod. Med. 1987; 32: 822-6.

26 Kadir RA, Economides DL, Sabin CA, Owens D, Lee CA Frequency of inherited bleeding disorders in women with menorrhagia. Lancet 1998; 351: 485-9.

27 Apter D, Viinikka L, Vihko R. Hormonal patterns of adolescent menstrual cycles. J. Clin. Endocr. Metab. 1978; 47: 944-54.

28 Garden AS. Problems with menstruation. In Garden AS, ed Paediatric and Adolescent Gymaecology. Arnold; 1998: 12754.
29 Hallberg L, Hultén L. Iron requirements, iron balance and iron deficiency in menstruating and pregnant women. In: Hallberg L, Asp NG, eds. Iron Nutrition in Healtb and Disease. London, Libbey, 1996: 165-82.

30 Cheong RL, Kuizon MD, Tajaon RT. Menstrual blood loss and iron nutrition in Filipino women. SE Asian J. Trop. Med. Publ. Health 1991; 22: 595-604.

31 Brabin L, Ikimalo J, Dollimore N, et al. How do they grow? A study of south-eastern Nigerian adolescent girls. Acta Paediatr. 1997; 86: 1114-20.

32 Cohen BJB, Gibor Y. Anaemia and menstrual blood loss Obstet. Gynecol. Surv. 1980; 35: 597-618.

33 Fazio-Tirrozzo G, Brabin L, Brabin B, Agbaje O, Harper G, Broadhead R. A community based study of vitamin $A$ and vitamin E status of adolescent girls living in the Shire Valley, southern Malawi. Eur. J. Clin. Nutr. 1998; 52: 1-6.

34 Shaw RW. Assessment of medical treatments for menorrhagia Br. J. Obstet. Gynaecol. 1994; 101: 15-18.

35 Iyer $V$, Farquhar $C$, Jepson $R$. The effectiveness of oral contraceptive pills versus placebo or any other medical treatments for menorrhagia. In: Farquhar C, Cooke I, Barlow D, eds. Menstrual Disorders and Subfertility Module of the Cocbrane Database of Systematic Reviews. Oxford; the Cochrane Collaboration Issue 4, 1998.

36 West CP. Dysfunctional uterine bleeding. Prescribers J. 1994; 34: $215-20$.

37 Collaborative Group on Hormonal factors in Breast Cancer. Breast cancer and hormonal contraceptives: collaborative reanalysis of individual data on 53,297 women with breast cancer and 100,239 women without breast cancer for 54 epidemiological studies. Lancet 1996; 347: 1713-27.

38 Hallberg L, Hultén L, Bengtsson C, Lapidus L, Lindstedt G. Iron balance in menstruating women. Eur. J. Clin. Nutr. 1995. 49: 200-7.

39 Robinson JC, Plichta S, Weisman CS, Nathanson CA, Ensminger M. Dysmenorrhoea and use of oral contraceptives in adolescent women attending a family planning clinic. $\mathrm{Am}$. J. Obstet. Gynecol. 1992; 166: 578-83.

40 Naeye RL. Teenaged and pre-teenaged pregnancies. Consequences of the fetal-maternal competition for nutrients. Pediatrics 1981; 67: 146-50. 